\title{
The evidences of innovative teaching the critical and creative thinking, integrated and problem-solving abilities in RN-BSN students
}

\author{
Ya-Lie Ku*1, Pei-Yu Lee ${ }^{1}$, Shih-Ming Kuo ${ }^{2}$ \\ ${ }^{1}$ Department of Nursing, College of Nursing, Fooyin University, Kaohsiung City, Taiwan, ROC \\ ${ }^{2}$ Department of Occupational Safety and Hygiene, Fooyin University, Taiwan, ROC
}

Received: May 29, 2020

DOI: $10.5430 /$ jnep.v11n2p19
Accepted: September 14, $2020 \quad$ Online Published: October 19, 2020

URL: https://doi.org/10.5430/jnep.v11n2p19

\begin{abstract}
Background: The principal investigator has integrated the teaching strategies and activities of critical and creative thinking with integration and problem-solving abilities in the process of guiding nursing students in the course of Nursing Practicum Project Production (NPPP) for seven years. Although the course has developed a set of indicators for evaluating the products; however, there is a lack of indicators of evaluating the critical and creative thinking, integration and problem-solving abilities of the nursing students. In the 2018 year, the professional growth program for the teachers through the expert meeting and faculties discussion has developed the indicators of evaluating the critical and creative thinking, integration and problem-solving abilities for the nursing students completing the course of NPPP. The purpose of this study was to explore the evidences of the innovative teaching among the critical and creative thinking, integration and problem-solving abilities of nursing students before and after the course of NPPP.

Methods: The mixed methods including the quasi-experimental and four factor designs were used in this study and the samples were the two-year program nursing students of the AB classes with the majority of them who have had the clinical working experiences. A class was the experimental group, integrating the teaching strategies and activities of critical and creative thinking, integration and problem-solving abilities. B class was used the traditional teaching. The two classes of nursing students were conducted self-assessment of the critical and creative thinking, integration and problem-solving abilities before and after the 2019 course of NPPP to understand the effectiveness of innovative teaching in the critical and creative thinking, integration and problem-solving abilities of RN-BSN students.

Results: The critical and creative thinking, integration and problem-solving abilities of RN-BSN students in A class not only has improved significantly after conducting the innovative teaching, but also has the higher scores than the comparison B class. Additionally, no matter the principal investigator or other two faculties instructed the A group of RN-BSN students, the critical and creative thinking as well as the integration and problem solving abilities of RN-BSN students have improved before and after the NPPP course although there is the tendency of decreasing four abilities from group 1 to 4 , but did not approach in the significant level.

Conclusions: It is the evidences of the innovative teaching of critical and creative thinking, the integration and problem solving abilities for RN-BSN students in the first five weeks of the NPPP course. Additionally, the principal investigator instructed the group 1 and 2 that performed better than group 3 and 4 by the other two instructors that might be interesting to further study the group 1 and 2 dynamics as beneficence of teaching those thinking and abilities by the principal investigator.
\end{abstract}

Key Words: Critical thinking, Creative thinking, Integration, Problem-solving

*Correspondence: Ya-Lie Ku; Email: ns126@ fy.edu.tw; Address: Department of Nursing, College of Nursing, Fooyin University, Kaohsiung City 83102, Taiwan, ROC. 


\section{INTRODUCTION}

In 2004, Taiwan's Ministry of Education ${ }^{[1]}$ proposed the implementation of creative education, and since then, many technological universities have offered creative courses aimed at increasing industry-academic cooperation opportunities to investigate innovative products, apply patents, and construct marketing plans. Additionally, professional nursing organizations have encouraged nursing personnel to produce innovative products that improve patient care, comfort, and satisfaction. ${ }^{[2,3]}$ Drawing inspiration from the innovative competitions organized by the Ministry of Education and professional nursing organizations, I conducted a series of creative studies.

Initially, the framework of creative thinking instruction for RN-BSN students was based on the creative process of clinical nurses, determined through qualitative study. ${ }^{[4]} \mathrm{Next}$, an 18-week nursing practicum project was developed that merged creative thinking teaching methods for the 2-year RN-BSN program with the 12 -step teaching process. ${ }^{[5]} \mathrm{Ad}-$ ditionally, the original 100-item questionnaire was built and revised to comprise 50 items focused on factors influencing the creative process; this questionnaire was administered as a pilot test to $30 \mathrm{RN}-\mathrm{BSN}$ students for quantitative research. A formal survey was conducted in nursing schools from $\mathrm{Au}$ gust 2012 to July 2013 in which the questionnaire was issued to $316 \mathrm{RN}-\mathrm{BSN}$ students from various nursing programs in Taiwan. Cronbach's $\alpha$ values for the questionnaire ranged from .86 to .92 for each scale, and the total explanation of variance ranged from $52.95 \%$ to $65.4 \%$ in exploratory factory analysis $(\mathrm{N}=116)$; the final 27 items, which comprised 4 subscales of factors influencing the creative process, were validated through a confirmatory factor analysis. ${ }^{[6]}$

The 18-week nursing practicum has become a capstone course, and 150 nursing students exhibited significantly enhanced creative characteristics and abilities by the end of the course. Before the course, they perceived the strongest predictors of their creativity to be abilities and barriers, whereas after the course, they perceived characteristics and motivations as the strongest predictors. ${ }^{[7]}$ Finally, AMOS 21.0 was used to verify the framework of factors influencing the creative process for the $150 \mathrm{RN}-\mathrm{BSN}$ students: abilities and barriers were moderately correlated to the motivation of creativity, whereas characteristics were highly correlated with abilities but poorly correlated with barriers. No relationship was observed between abilities and barriers. ${ }^{[8]}$

Overall, from 2014 through 2018, I developed research and faculty development groups in the school. ${ }^{[9-11]}$ and extended the project to other nursing schools. ${ }^{[12]}$ The nursing practicum course implemented for nursing faculties and 2 year nursing students resulted in more than 60 patents and more than 30 domestic and foreign innovative competition awards. Nevertheless, it was still unclear whether the innovative teaching approach enhanced the critical and creative thinking, integration, and problem-solving abilities of RNBSN students after they completed the course.

\subsection{Purpose}

Therefore, this study explored the effectiveness of innovative teaching in enhancing the critical and creative thinking, integration, and problem-solving abilities of RN-BSN students by comparing their performance with that of a nursing practicum project class of RN-BSN students that did not use the innovative teaching approach.

\subsection{Literature review}

The evidence-based literature on nursing education has mainly focused on critical thinking and problem-solving abilities, but few studies have explored creative thinking, and none have explored integration. Regarding to the critical thinking ability, one systematic review analyzed 12 teaching interventions in 8 countries identified and found inconsistent results in critical thinking improvement: critical thinking significantly improved in $60.7 \%$ (17/28), did not improve in $32.1 \%(9 / 28)$, and even decreased in $7.2 \%(2 / 28)$ (Carter et al., 2016). Furthermore, $50 \%(8 / 16)$ of the studies reported that specific simulation training positively influenced critical thinking skills but the other $50 \%$ (8/16) found it to be ineffective in improving critical thinking. ${ }^{[13]}$ Compared with traditional teaching methods; however, concept mapping improved critical thinking in all students according to a systematic review and meta-analysis of $11-13$ trials. ${ }^{[14]}$

In terms of problem-solving ability, project-based learning (PBL) is the most widely used teaching strategy in undergraduate nursing programs for improving critical thinking. ${ }^{[15]}$ Some systematic reviews and meta-analyses have identified PBL was an important component for improving critical thinking among undergraduate nursing students. ${ }^{[16,17]}$ In addition to quantitative evidences, a qualitative systematic review of 378 articles on PBL also identified 51 findings with five categories: understanding purpose and process, nursing tutors, quality of group interactions, clinical reasoning, and learning process. ${ }^{[18]}$

Regarding to the creative thinking ability, Chan ${ }^{[19]}$ systematically reviewed the literature on creative thinking in nursing education and identified four themes in the content of teaching creativity: learning with confidence, learning through group cooperation, diverse learning, and freedom to learn. Additionally, an integrative literature review of innovative strategies in higher education demonstrated four themes: dig- 
ital simulation, dissonance between concepts and approaches to teaching, mixed approaches, and large class size. ${ }^{[20]}$ Moreover, an integrative review of 15 quantitative and 7 qualitative studies by analyzing and synthesizing the existing evidences on creativity in nursing revealed that the following intrinsic and extrinsic factors affect the creativity of nurses and nursing students: the intrinsic factors were learning and thinking styles, passion and interest in nursing, and achievement motivation, and the extrinsic factors were workplace problems and shortage of nurses. ${ }^{[21]}$ Furthermore, a cross-sectional descriptive study of 74 nursing faculties and 245 nursing students revealed that creative personality did play a moderating role between school creative environment and nursing students' creativity. ${ }^{[22]}$ Finally, Ma et al. ${ }^{[21]}$ also reported that self-directed learning, group work, and artistic expressions such as painting, music, and pottery could improve the creativity of nurses and nursing students.

\section{MethodS}

\subsection{Research design, participants and procedures}

This study used mixed designs by first the quasi-experimental design with $\mathrm{AB}$ classes taking the nursing practicum project production (NPPP) courses and the principal investigator conducted the teaching strategies of critical and creative thinking, the integration and problem solving abilities in the A class; while the co-investigator conducted the traditional teaching in the B class. Secondly, four factors designs applied the teaching strategies of critical and creative thinking, the integration and problem solving abilities in the four groups of A class. Both of RN-BSN students in the AB classes conducted the self-evaluation of critical and creative thinking, the integration and problem solving abilities before and after the NPPP courses from Feb to June, 2019.

The participants of this study were $100 \mathrm{RN}-\mathrm{BSN}$ students in $A B$ classes with 51 in the A class and 49 in the B class. The characteristics of studying samples were the clinic registered nurses from the different fields such as emergency, ICU, medical, surgical, obstetrics, pediatric, community, and psychiatric units. The majority of them have worked more than two years in the local and district hospitals or medical centers; therefore, they have had more comprehensive understanding of the clinical plights and problems with the independent and active learning attitudes and abilities.

\subsection{Innovative Teaching Strategies}

The investigator developed the teaching strategies of critical and creative thinking, the integration and problem solving abilities for the NPPP course. A class was the experimental group applying the teaching strategies and activities of critical and creative thinking, the integration and problem solving abilities. Whereas B class was the control group using the traditional teaching strategies and discussion. There are four groups of RN-BSN students with three instructors in each of $\mathrm{AB}$ classes; while the principal investigator and co-investigator instructed two groups of nursing students in each $\mathrm{AB}$ classes individually; whereas the other two faculties instructed two groups of nursing students individually.

In terms of the experimental A class, the innovative teaching of critical and creative thinking, the integration and problem solving abilities were conducted in the first five weeks of the NPPP course. Initially, the principal investigator probed the RN-BSN students to think about the difficulties during their clinical working process and compare each plight by the possibility of resolution with the critical thinking teaching strategies and activities. Lately, brainstorming was used to inspire the RN-BSN students to think the related factors influencing the plight and organized them into the different categories. Ten RN-BSN students were drawing the unique pictures of nursing products by following the different categories in the purpose of solving the clinical plight. The group of RN-BSN students were discussed and decided to have the first draft of the innovative nursing product following integrating the above ten drawing pictures of nursing products. Furthermore, the RN-BSN students compared and analyzed their first draft of innovative product with the products searching from the patents and internets for the purpose of comparing the strengths and weakness of each product with their innovative one to make the judgement and decision of the revised direction of their second draft innovative product.

Until now, the group of RN-BSN students have practiced the critical thinking in terms of comparison, analysis, judgement, and decision-making, as well as the creative thinking by the concepts of fluency, flexibility, uniqueness, originality, association, constitution, transformation, and replacement. Additionally, the innovation teaching of integration included discussion about the accuracy of rationale, consistency with the clinical plight, complete consideration, and evidence value of the innovative product. Finally, the innovation teaching of problem-solving included leading the RN-BSN students to reflect the plight with the group consensus and evaluated the process of producing the innovative product accurately to be able to solve the original clinical problems.

\subsection{Instruments}

In the 2018 year, the professional growth community program for the teachers through the expert meeting and faculties discussion has developed the indicators of evaluating the creative thinking, critical thinking, integrated application and problem-solving abilities for the nursing students com- 
pleting the course of NPPP. The definitions and evaluating indicators of the critical and creative thinking, the integration and problem solving abilities are demonstrating in the Table 1 .

There are four definitions of the critical and creative thinking, the integration and problem solving abilities including four evaluating indicators under each definition. One hundred RN-BSN students in the AB classes have self-evaluated their critical and creative thinking, the integration and problem solving abilities by 16 indicators following 1-5 Likert scale from extremely agree, agree, general, disagree, to extremely disagree before and after the NPPP course.

Table 1. Evaluating indicators of the critical and creative thinking, integration and problem solving abilities

\begin{tabular}{|c|c|c|c|c|c|c|}
\hline $\begin{array}{l}\text { Thinking and } \\
\text { Abilities }\end{array}$ & Evaluating Indicators & Self-Evalu & tion & & & \\
\hline \multirow{5}{*}{$\begin{array}{l}\text { Critical } \\
\text { Thinking }\end{array}$} & $\begin{array}{l}\text { Definition: Students could understand and apply the } \\
\text { concepts related to critical thinking during the critical } \\
\text { thinking process. }\end{array}$ & $\begin{array}{l}\text { Extremely } \\
\text { Agree }\end{array}$ & Agree & General & Disagree & $\begin{array}{l}\text { Extremely } \\
\text { Disagree }\end{array}$ \\
\hline & 1.I could understand and apply the comparability & & & & & \\
\hline & 2. I could understand and apply the analysis & & & & & \\
\hline & 3. I could understand and apply the judgement & & & & & \\
\hline & 4. I could understand and apply the decision-making & & & & & \\
\hline \multirow{5}{*}{$\begin{array}{l}\text { Creative } \\
\text { Thinking }\end{array}$} & $\begin{array}{l}\text { Definition: Students could understand and apply the } \\
\text { concepts related to creative thinking during the } \\
\text { creative thinking process. }\end{array}$ & & & & & \\
\hline & $\begin{array}{l}\text { 1. I could understand and apply fluency, flexibility, } \\
\text { and uniqueness }\end{array}$ & & & & & \\
\hline & 2. I could understand and apply originality & & & & & \\
\hline & $\begin{array}{l}\text { 3. I could understand and apply association, } \\
\text { connection, and constitution }\end{array}$ & & & & & \\
\hline & $\begin{array}{l}\text { 4. I could understand and apply transformation and } \\
\text { replacement }\end{array}$ & & & & & \\
\hline \multirow{5}{*}{ Integration } & $\begin{array}{l}\text { Definition: Students could understand and apply the } \\
\text { concepts related to integration during the integrating } \\
\text { process. }\end{array}$ & & & & & \\
\hline & 1. I could understand and apply accuracy & & & & & \\
\hline & 2. I could understand and apply consistency & & & & & \\
\hline & 3. I could understand and apply completeness & & & & & \\
\hline & 4. I could understand and apply evidences & & & & & \\
\hline \multirow{5}{*}{$\begin{array}{l}\text { Problem- } \\
\text { Solving }\end{array}$} & $\begin{array}{l}\text { Definition: Students could understand and apply the } \\
\text { concepts related to problem-solving during the } \\
\text { problem-solving process. }\end{array}$ & & & & & \\
\hline & 1. I could understand and apply problem identification & & & & & \\
\hline & 2. I could understand and apply consensus & & & & & \\
\hline & 3. I could understand and apply accurate conducting & & & & & \\
\hline & 4. I could understand and apply problem-solving & & & & & \\
\hline
\end{tabular}

\section{RESULTS}

Participation in Class A was 86.3\% (44/51) and in Class B it was $69.4 \%$ (34/49). Through MANOVA of reducing the within group variance, three assumptions should be fitted including enough sample sizes $(\mathrm{N}>10)$ among four groups, homogeneity indicating by Box's M $(* * p<.001)$, Bartlett test of sphericity as the significantly correlated with each other among critical thinking, creative thinking, integration, and problem-solving four variables $(* * p<.001)$; however, with a significant interaction effect among four abilities $(* * p$ $<.001$ ), the direct effects cannot be interpreted directly without adjustment (see Table 2).

Due to the violation of a significant interaction effect, the model must be adjusted and revealed that students in Class A significantly improved their critical and creative thinking, integration, and problem-solving abilities before/after the NPPP course among four groups (see Tables $3 \& 4$ ). 
Table 2. Assumptions of MANOVA

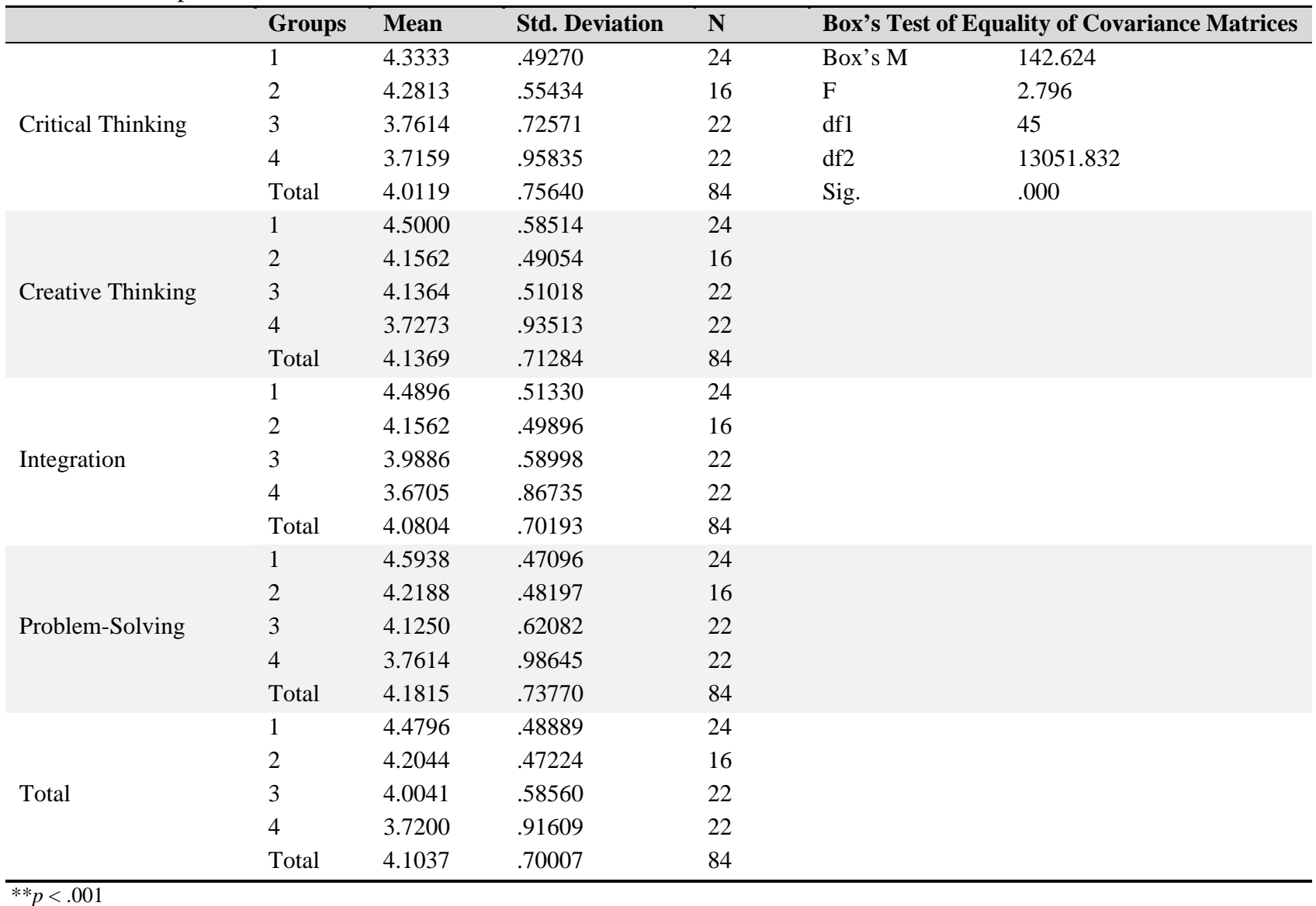

Table 3. Four abilities among four groups of a class before/after NPPP course

\begin{tabular}{llllll}
\hline Source & \multicolumn{1}{c}{ Dependent Variable } & df & Mean Square & F & Sig. \\
\hline \multirow{5}{*}{ Corrected Model } & Critical Thinking & 4 & 6.104 & 20.897 & .000 \\
& Creative Thinking & 4 & 3.248 & 8.791 & .000 \\
& Integration & 4 & 3.666 & 11.040 & .000 \\
& Problem-Solving & 4 & 4.844 & 14.837 & .000 \\
& Total & 4 & 4.234 & 14.089 & .000 \\
& Critical Thinking & 1 & 55.900 & 191.389 & .000 \\
Intercept & Creative Thinking & 1 & 88.329 & 239.094 & .000 \\
& Integration & 1 & 83.609 & 251.799 & .000 \\
& Problem-Solving & 1 & 75.369 & 230.845 & .000 \\
& Total & 1 & 75.309 & 250.589 & .000 \\
Before/After & Critical Thinking & 1 & 17.465 & 59.797 & .000 \\
& Creative Thinking & 1 & 6.129 & 16.589 & .000 \\
& Integration & 1 & 6.670 & 20.088 & .000 \\
& Problem-Solving & 1 & 11.321 & 34.676 & .000 \\
Troups & Total & 1 & 9.926 & 33.029 & .000 \\
& Critical Thinking & 3 & 2.707 & 9.269 & .000 \\
& Creative Thinking & 3 & 2.584 & 6.995 & .000 \\
& Integration & 3 & 2.975 & 8.960 & .000 \\
& Problem-Solving & 3 & 3.108 & 9.520 & .000 \\
\hline
\end{tabular}

${ }^{* *} p<.001$ 
Table 4. Effects of four abilities among four groups of a class before/after NPPP course

\begin{tabular}{lllllll}
\hline Effect & & Value & F & Hypothesis df & Error df & Sig. \\
\hline \multirow{4}{*}{ Intercept } & Pillai's Trace & .778 & $52.486^{\#}$ & 5.000 & 75.000 & .000 \\
& Wilks' Lambda & .222 & $52.486^{\#}$ & 5.000 & 75.000 & .000 \\
& Hotelling's Trace & 3.499 & $52.486^{\#}$ & 5.000 & 75.000 & .000 \\
& Roy's Largest Root & 3.499 & $52.486^{\#}$ & 5.000 & 75.000 & .000 \\
Before/ & Pillai's Trace & .543 & $17.820^{\#}$ & 5.000 & 75.000 & .000 \\
After & Wilks' Lambda & .457 & $17.820^{\#}$ & 5.000 & 75.000 & .000 \\
& Hotelling's Trace & 1.188 & $17.820^{\#}$ & 5.000 & 75.000 & .000 \\
& Roy's Largest Root & 1.188 & $17.820^{\#}$ & 5.000 & 75.000 & .000 \\
\multirow{3}{*}{ Group } & Pillai's Trace & .623 & 4.033 & 15.000 & 231.000 & .000 \\
& Wilks' Lambda & .478 & 4.245 & 15.000 & 207.443 & .000 \\
& Hotelling's Trace & .888 & 4.362 & 15.000 & 221.000 & .000 \\
& Roy's Largest Root & .499 & $7.681^{\dagger}$ & 5.000 & 77.000 & .000 \\
\hline
\end{tabular}

${ }^{* *} p<.001{ }^{\#}$ Exact statistic; ${ }^{\dagger}$ The statistic is an upper bound on $\mathrm{F}$ that yields a lower bound on the significance level

Additionally, according to Figures 1 to 4, critical thinking, creative thinking, integration, and problem-solving four abilities were decreased from group 1 to 4 ; however, it did not approach at the significant level by post hoc Scheffe $(p>.05)$ (see Table 5).

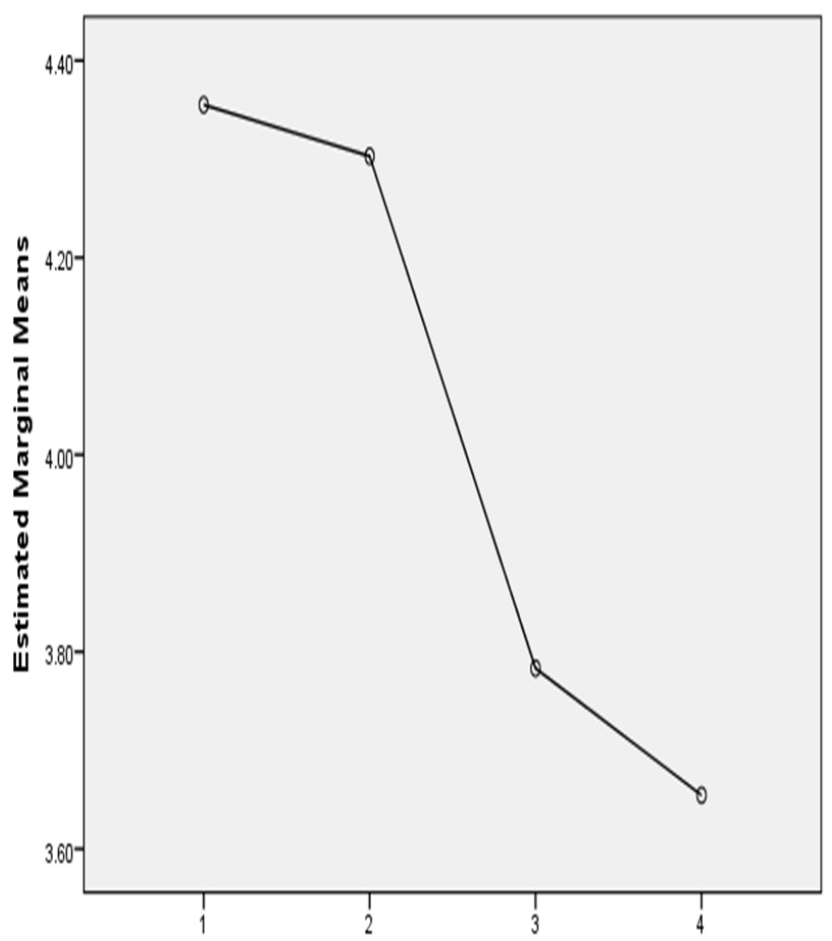

Figure 1. Critical thinking among 4 groups

Finally, Class A students in the experimental group by the innovation teaching had significantly higher scores than Class $\mathrm{B}$ students in the traditional teaching group on all four abilities after NPPP course (see Table 6).

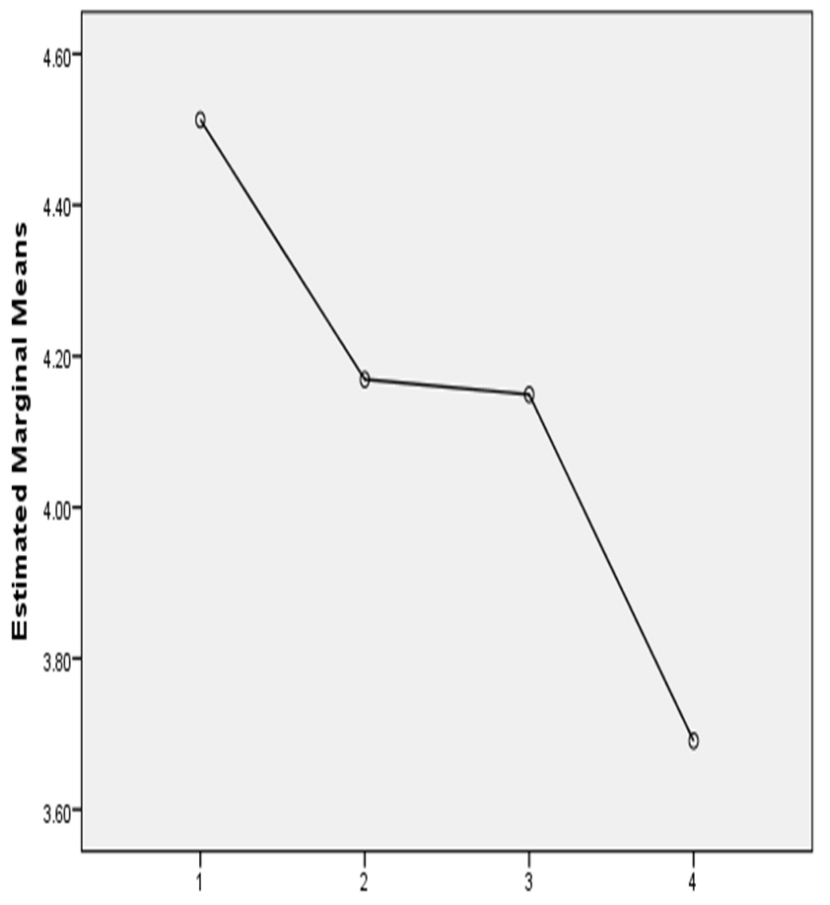

Figure 2. Creative thinking among 4 groups

\section{Discussion}

Literature in nursing education majorly focused on the evidences of innovative teaching among the critical thinking with PBL and creative thinking; however, no integration information was found. However, integration abilities were taught and merged into the other three abilities in this study. Additionally, motivation, characteristics, personality were the important factors of cultivating creative abilities for nursing students. However, no exploration of above variables for nursing students in this study. Furthermore, it is still not clear if the critical and creative thinking, the integration and problem solving abilities could be accounted individually or they have merged into together because PBL often was cred- 
ited in part of critical thinking components as the literature mentioned. However, four abilities of critical and creative thinking as well as the integration and problem-solving were all interacted with each other in this study.

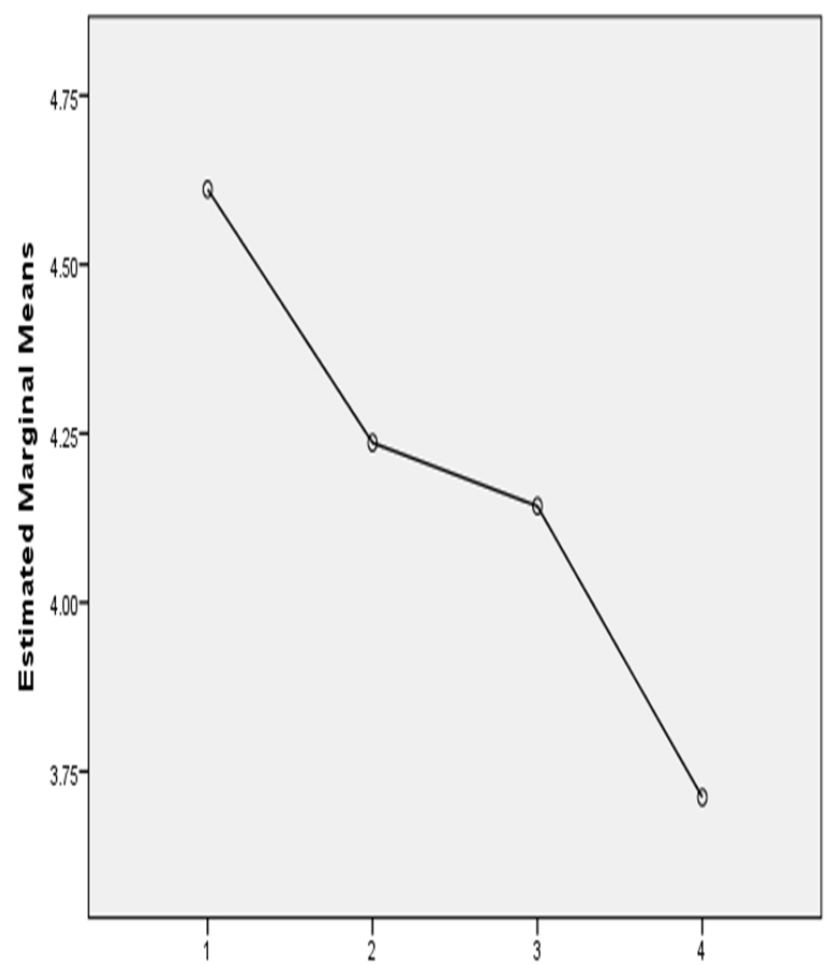

Figure 3. Integration among 4 groups

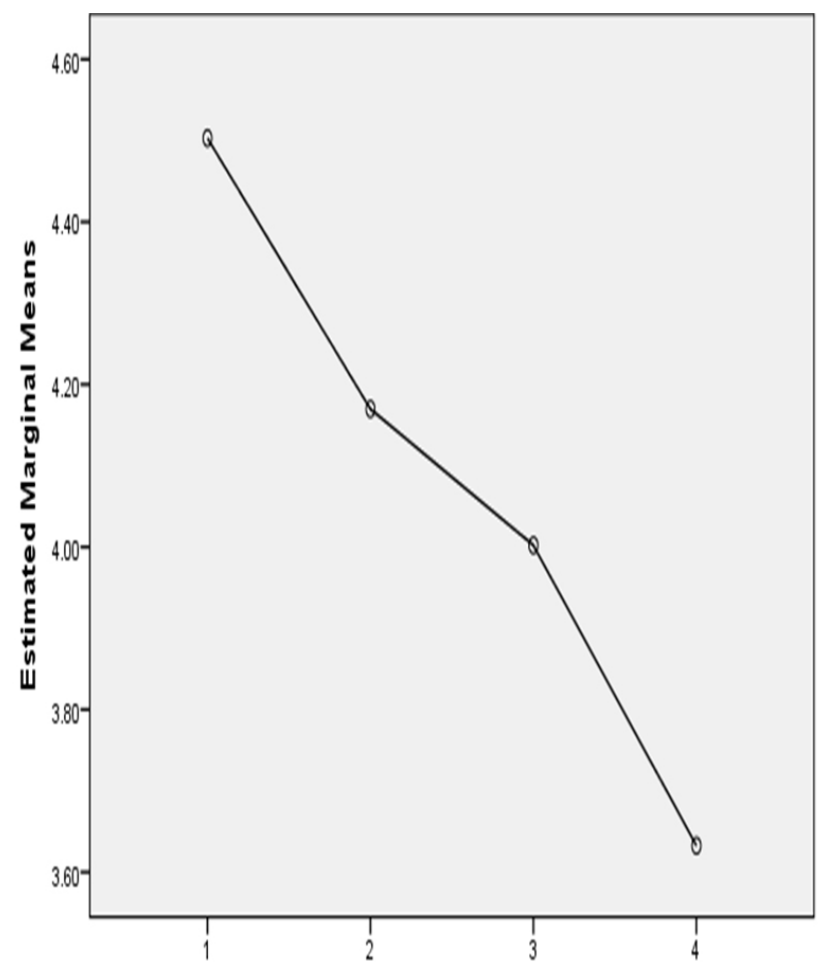

Figure 4. Problem-solving among 4 groups
Table 5. Critical thinking, creative thinking, integration, and problem-solving among four groups

\begin{tabular}{|c|c|c|c|c|}
\hline \multirow{2}{*}{ Four Abilities } & \multirow{2}{*}{ Groups } & \multirow{2}{*}{$\mathbf{N}$} & \multicolumn{2}{|l|}{ Subset } \\
\hline & & & 1 & 2 \\
\hline \multirow{5}{*}{ Critical Thinking } & 4 & 22 & 3.7159 & \\
\hline & 3 & 22 & 3.7614 & \\
\hline & 2 & 16 & & 4.2813 \\
\hline & 1 & 24 & & 4.3333 \\
\hline & Sig. & & .992 & .988 \\
\hline \multirow{6}{*}{ Creative Thinking } & & & 1 & 2 \\
\hline & 4 & 22 & 3.7273 & \\
\hline & 3 & 22 & 4.1364 & 4.1364 \\
\hline & 2 & 16 & 4.1562 & 4.1562 \\
\hline & 1 & 24 & & 4.5000 \\
\hline & Sig. & & .122 & .240 \\
\hline \multirow{6}{*}{ Integration } & & & 1 & 2 \\
\hline & 4 & 22 & 3.6705 & \\
\hline & 3 & 22 & 3.9886 & \\
\hline & 2 & 16 & 4.1562 & 4.1562 \\
\hline & 1 & 24 & & 4.4896 \\
\hline & Sig. & & .053 & .294 \\
\hline \multirow{6}{*}{ Problem-Solving } & & & 1 & 2 \\
\hline & 4 & 22 & 3.7614 & \\
\hline & 3 & 22 & 4.1250 & 4.1250 \\
\hline & 2 & 16 & & 4.2188 \\
\hline & 1 & 24 & & \\
\hline & Sig. & & .145 & .946 \\
\hline
\end{tabular}

Table 6. AB classes after the nursing practicum project production course

\begin{tabular}{lllllll}
\hline Items & Class & $\mathbf{N}$ & Mean & SD & $\boldsymbol{t}$ & Sig \\
\hline Critical & $\mathrm{A}$ & 44 & 17.50 & 2.783 & \multirow{2}{*}{3.377} & .001 \\
Thinking & $\mathrm{B}$ & 34 & 15.41 & 2.607 & & \\
Creative & $\mathrm{A}$ & 44 & 17.73 & 2.203 & & \\
Thinking & $\mathrm{B}$ & 34 & 13.85 & 2.642 & & .000 \\
& $\mathrm{~A}$ & 44 & 17.32 & 2.683 & & \\
Integration & $\mathrm{B}$ & 34 & 15.18 & 2.668 & & .001 \\
Problem- & $\mathrm{A}$ & 44 & 18.05 & 2.251 & & \\
Solving & $\mathrm{B}$ & 34 & 15.15 & 3.056 & & .000 \\
\hline
\end{tabular}

Finally, group cooperation and team work were valued in the teaching critical thinking with PBL and creative thinking, but no further data identified what kind of group dynamics as beneficence of teaching those thinking and abilities. In this study, the critical thinking, creative thinking, integration, and problem-solving four abilities among four groups were improved significantly when comparing before and after NPPP course; however, there is the tendency of decreasing four abilities from group 1 to 4 , but did not approach in the significant level. In other words, the principal investigator instructed the group 1 and 2 that performed better than group 3 and 4 
by the other two instructors. It will be interesting to further study the group 1 and 2 dynamics as beneficence of teaching those thinking and abilities by the principal investigator.

\section{Conclusion}

The critical and creative thinking, integration and problemsolving abilities of RN-BSN students in A class not only has improved significantly after conducting the innovative teaching, but also has the higher scores than the comparison B class. Additionally, no matter the principal investigator or other two faculties instructed the A group of nursing students, the critical and creative thinking as well as the integration and problem solving abilities of RN-BSN students have improved before and after the NPPP course. It is the evidences of the innovative teaching of critical and creative thinking, the integration and problem solving abilities for RN-BSN students in the first five weeks of the NPPP course. The importance of the critical and creative thinking as well as the integration and problem solving abilities of RN-BSN students is that the students could expand the thinking and abilities they have learned in the NPPP course into the clinical nursing works to solve the health problems or plight of the patients or improve their quality of care.

\section{LIMITATION AND RECOMMENDATION}

The limitation of this study was the less participating rate and the higher attrition rate before and after the NPPP course in the control group than the experimental group. Additionally, the principal investigator suggested that the future study is to follow the clinical performances for those who have taken the innovation teaching of the NPPP course with those who do not for evaluating their clinical performances in terms of the differences in the critical and creative thinking as well as the integration and problem solving abilities. By doing so, the evidences of innovation teaching in the critical and creative thinking as well as the integration and problem solving abilities of RN-BSN students could be valued into their professional nursing career.

\section{CONFlicts of INTEREST Disclosure}

The authors declare that there is no conflict of interest.

\section{REFERENCES}

[1] Minister of Education. Current Status of Creative Education in Taiwan retrieved from Minister of Education Internet, 2004. Available from: http://www.creativity.edu.tw

[2] Taiwan Nurse Association Message. Taiwan Nurse Association, 2005 Available from: http://www.twna.org.tw

[3] Nursing Magazine. The National Union of Nurses' Association, 2004 2020. Available from: http://www.nurse.org.tw

[4] $\mathrm{Ku} \mathrm{YL,} \mathrm{Kuo} \mathrm{CL.} \mathrm{Develop} \mathrm{a} \mathrm{teaching} \mathrm{framework} \mathrm{of} \mathrm{creative} \mathrm{thinking}$ in nursing education on the creative process of clinical nurses in Taiwan. Innovations in Education and Teaching International. 2016; 53(4): 424-434.

[5] Ku YL, Lee PY, Shen MH, et al. Constructing and Evaluating a Nursing Capstone Course for Cultivating Creativity in RN-BSN Students in Taiwan. Journal of Nursing Education and Practice. 2014; 4(7): $1-10$.

[6] Ku YL, Lee PY, Tu CT, et al. Validating the questionnaire of factors influencing creative process for RN-BSN students in Taiwan. Journal of Nursing Education and Practice. 2015; 5(5): 55-64.

[7] Lee PY, Tu CT, Shen MH, et al. Effectiveness of a nursing capstone project course in enhancing nursing student creativity. Innovative Journal of Medical and Health Science. 2016; 6(3): 69-75.

[8] Ku YL, Tu CT, Kuo CL, et al. Validating the Framework of Factors Influencing Creative Process for RN-BSN Students in Taiwan. International Journal of Advanced Scientific Research. 2016; 1(7): 43-47.

[9] Ku YL, Shen MH, Lee PY, et al. The Application of Creative Thinking Teaching in the Course of Nursing Capstone Project. Chung Gang Nursing. 2014; 25(2): 157-166.
[10] $\mathrm{Ku}$ YL, Lee PY, Wang YC, et al. Innovative Nursing Products Created by the Nursing Teachers and Students in Taiwan. Asian Journal of Science and Technology. 2016; 7(11): 3804-3810.

[11] Ku YL, Shen MH, Lee PY, et al. Obtaining patents for innovative products designed by nursing faculty members in Taiwan. International Journal of Innovative Research in Medical Science. 2017; 4(2): 679-685.

[12] Liu HY, Kuo CL, Shen MH, et al. Evaluating faculties and students' satisfaction of a nursing practicum project workshop in Northern Taiwan. Journal of Nursing Research and Practice. 2018; 2(2): 16-19.

[13] Adib-Hajbaghery M, Sharifi N. Effect of simulation training on the development of nurses and nursing students' critical thinking: A systematic literature review. Nursing Education Today. 2017; 50: 17-24. PMid:28011333 https://doi.org/10.1016/j.nedt. 2016.12 .011

[14] Yue M, Zhang M, Zhang C, et al. The effectiveness of concept mapping on development of critical thinking in nursing education: A systematic review and meta-analysis. Nursing Education Today. 2017; 52: 87-94. PMid:28273528 https ://doi.org/10.1016/j.nedt .2017 .02 .018

[15] Carvalhoa DPSRP, Azevedoa IC, Cruza GKP, et al. Strategies used for the promotion of critical thinking in nursing undergraduate education: A systematic review. Nursing Education Today. 2017; 57: 103-107. PMid:28783526 https://doi.org/10.1016/j.nedt.2017.07 .010

[16] de Oliveira LB, Díaz LJR, da Costa Carbogim F, et al. Strategies used for the promotion of critical thinking in nursing undergraduate education: A systematic review. Nursing Education Today. 2016; 50(2): 350-359.

[17] Kong LN, Qin B, Zhou YQ., et al. The effectiveness of problembased learning on development of nursing students' critical thinking: A systematic review and meta-analysis. International Journal 
of Nursing Studies. 2014; 51: 458-469. PMid:23850065 https: //doi.org/10.1016/j.ijnurstu.2013.06.009

[18] Wosinskic J, Belcherb AE, Dürrenbergera Y, et al. Facilitating problem-based learning among undergraduate nursing students: A qualitative systematic review. Nursing Education Today. 2013; 60: 67-74.

[19] Chan ZCY. A systematic review of creative thinking/creativity in nursing education. Nursing Education Today. 2013; 33: 1382-1387. PMid:23044463 https://doi.org/10.1016/j.nedt. 2012.09 .005
[20] Santosa J, Figueiredob AS, Vieirab M. Innovative pedagogical practices in higher education: An integrative literature review. Nursing Education Today. 2019; 72: 12-17.

[21] Ma X, Yang Y, Wang X, et al. An integrative review: developing and measuring creativity in nursing. Nursing Education Today. 2018; 62: 1-8. PMid:29274494 https : //doi .org/10.1016/j. nedt. 2017. 12.011

[22] Liu HY. Factors affecting nursing students' creativity in Taiwan: Exploring the moderating role of creative personality. Nursing Education Today. 2020; 88: 1-6. PMid:32070911 https://doi.org/ $10.1016 / j$.nedt .2020 .104367 